\title{
The Effects of Quality Control Circle on Employee Perceptions and Attitudes in Selected Companies: Kingdom of Bahrain
}

\author{
Dr. Marluna Lim Urubio \\ Assistant Professor, Department of Management and Human Resources, College of Financial Sciences, AMA
}

International University-Bahrain, Salmabad, Kingdom of Bahrain

\begin{abstract}
The research is about the effects of quality control on Nestle Waters' employees' perception and attitudes. Descriptive research was used for this research along with the use of instruments like questionnaire, unstructured interviews, documentary analysis. The questionnaire that was used has five (5) parts namely: the technical portion of the QCC (quality control circle), the QCC process, effectiveness of the circle, general feelings about the QCC and the organization and lastly the background of respondents. Statistical treatments were used to process the data and answer the questions about the relationship of training adequacy to QC effectiveness and leadership in the QCC. Sub questions that were answered were the general feelings of the employees toward the QCC and the organization as well, the perception of the QCC members on job satisfaction and commitment to organizational goals and values. The employees were even asked to rate the contribution of the various people in the organization. The findings of the study when it comes to the relationship of training adequacy to QCC effectiveness and the leadership of the Quality Control Circle (QCC), shows that there is relationship between adequacy of training and QCC effectiveness. However, correlation between training adequacy and the leadership of QCC, is weak. On the general feeling of members towards the Quality Control Circle and the organization, the employees have a positive feelings and /or perceptions, same as when they were asked about Job satisfaction and commitment to organizational goals and values. Employees also believed that the contribution of various people in the organization is very important. Based from the findings, a set of conclusion and recommendations were given. Trainings are helpful for each and everyone in the company, and therefore, Nestle Waters should continue to give trainings based on the needs of the employee. For shaping future QCC leaders, an appropriate training should be given to them as employees of Nestle Waters perceived a lack of appropriate trainings to develop QCC leaders. On the general feelings of the respondents about the QCC and the Organization, the respondents gave positive responses that proved how happy they are with the organization and their commitment to put extra effort for the QCC. The organization should continue its practices to support this. About the perception of the QCC members on Job satisfaction and commitment to organizational goals and values, it is the conclusion of the researcher that respondents can see the importance that the employees are happy and satisfied about their job. Also it can be concluded that based from the responses of the employees, they believe that within the organization, everybody is important. Nestle waters should strengthen its programs that will further enhance commitment to work and job satisfaction as well as devise rewards program to further motivate its employees.
\end{abstract}

Keywords: Quality Control Circle, productivity, QCC effectiveness, Job satisfaction, Commitment, Organizational Goals and Values.

\section{INTRODUCTION}

In any company, whether it is a manufacturing company with everyone helping each other. With the many concerns or service company, serious concern for productivity, top management is facing which is normally strategy safety, delivery, employee morale and quality are major based, operations problem for them is much less a concern issues that need to be addressed if one wants to be [3]. However, as this operations problem is entirely competitive [1]. Competitiveness occurs when price is difficult to see but when these little issues are ignored, lower, when productivity is higher, when there is no extra cost incurred due to accident, when employees work well because of high morale and finally, when all products and services are delivered on time [2].

Improving on these aspects is the only way to competitiveness. Any business which wants to succeed should ensure that they have quality products and services, on time delivery and shipment, increased productivity, minimized if not zero accident and high employee morale. However, it is a reality that there is no perfect organization and somehow improvements should be done somewhere

they become big problems and headaches.

Typical management or the so called conservative management type will only get a very limited participation from its employees for problem analysis and/or involvement in decision making [4]. The conservative ones believe that it is only the top management who should solve the problem and make the decisions. In this type, there is a very little participation from the employees or workers. However, nowadays, the management style has changed from so called conservative to the more participative one. Modern management styles allow 
greater participation and empowerment of its employees in problem analysis and suggestions for decision making [5]. However, the means by which greater employee participation is allowed had been debated on by many management experts. There are several ways to allow greater employee participation, but the more accepted and practiced one is the creation and utilization of a Quality Control Circle. Quality Control Circle or QCC is the more widely acceptable way of encouraging employee participation and empowerment [6]. The implementation of the Quality Control Circle started in Japan where it has earned positive remarks for the contributions that the Quality Control Circles have done in terms of company productivity, safety, delivery, quality and raising employee morale. Quality Control Circle is a small group, composed of 4-5 people ( others have it 6-8 people ) who voluntarily grouped themselves together, meeting regularly to solve issues which are common to them, using scientific methods to analyze the problem, make alternative solutions, recommend solution and implement the same recommendation upon approval by the higher management [7]. One of the main characteristics of QCC is its voluntarily participation and collaborative actions to come up with agreed decision. Membership or participation is never forced or never assigned. It has to come from the members themselves that they want to be part of the circle. The QCC uses scientific methods to analyze problems and situations. Among the many tools they are using include cause and effect diagram or the so called Ishakawa diagram, flowchart, histogram, scatter diagram, control chart, checksheet, pareto analysis, among others.

\section{RESEARCH METHODOLOGY}

Since the main objective of this research is to find on the effects of Quality Control Circle on employee perceptions and attitude in Nestle Waters, Kingdom of Bahrain, therefore this research used descriptive - evaluative approach in order to answer the questions posted in the statement of the problems. Descriptive research is an effective tool when the researcher wants to incorporate the accumulation of facts, data and figures [31]. The interpretative and explanatory style of the technique enabled the researcher to process the raw data and later develop the information that led to conclusions and recommendations

The data used to complete this research was obtained through the use of an acceptable questionnaire. The respondents for this particular research study are people who are involved with the Quality Control Circle. Respondents of the study will be in 2 groups. First Group will be the members of the QCC and the second group is composed of workers in the same company but not part of QCC. As mentioned in the sampling design, the research covered all the members of the 2 groups of QCC in Nestle Waters, Bahrain and a portion of the total population of the company which is 60 employees, both from operations and administration. Those who are in trucks and part of the distribution will not be included. The questionnaire used by the study referred to was designed in order to know the level of training being received by the QCC members, leadership, job satisfaction, job commitment as well as intention to quit the job. This intention to quit the job' has significance to QCC because being a member in QCC needs long term commitment from the worker or employee. The data were summarized, tabulated, analyzed and interpreted using frequency distribution, percentage distribution, weighted mean, one way ANOVA, cross tabulation

\section{RESULTS AND DISCUSSION}

1. The relationship between training adequacy to effectiveness and the leadership Quality Control Circle (QCC)

Pearson-r test results reveal that there is a very highly significant relationship between training adequacy and leadership: r-value of .694 and p-value of <.001 at .01 level of significance. Leadership of the quality circle as enhanced by the level and types of trainings is important so that it can deliver the tasks that are expected from a quality control circle like problem solving, increasing productivity and improving quality [35]

Hence, the null hypothesis which states that there is no significant relationship between training adequacy and leadership is hereby rejected.

On the other hand, Pearson-r test results also reveal that there is no significant relationship between training adequacy and effectiveness: r-value of .062 and p-value of .639 at .05 level of significance. The results of the study clearly shows that there is no existing relationship between adequacy of training, or the level and amount of training that has been given to QCC members and non members to how effective the QCC can function especially in terms of problem solving techniques.

2. General feeling of members towards the Quality Control Circle and the Organization?

From Table 5, it can be observed that the respondents' general feeling towards QCC is positive. When respondents expressed their strong agreement when asked about the importance of the company to them, how happy they are to give their extra efforts for the company and the willingness to tell friends about the company. Respondents also strongly agreed when they were asked about their commitment to always do their best for the company as well as the similarity of the individual goals and values with that of the company.

On the other hand, when respondents were asked about thinking of quitting the job should they find an equal or better job, they strongly agreed. Based from one research done by Kimberly Buch, which was done in four (4) organizations, respondents gave different responses on different items but were unanimous that circle members have positive perception about the QCC and the organization. Employees, both QCC and non QCC displayed positives responses in terms of absenteeism, turn over and productivity [36]. Overall, this result shows that the respondents are valu.ng their company as they can identify their goals and values with Nestle Waters.

3. The perception of the QCC members on Job satisfaction and commitment to organizational goals and values. 
QCC members believed that for the QCC to be highly successful and achieve organizational goals, the ability of members (4.50) as well as the ability and commitment of QCC leader (4.54) are extremely important. Others factors also contribute to the above like the commitment and participation to the QCC and aggressiveness of the members, not to ignore the ability and commitment of the facilitators. Also rated as somewhat important for job satisfaction and commitment to achieve organizational goals are management recognition, training acquired by the members and cooperation among members.

The study conducted for the emergency medical services proved that the quality circle implementation has a positive impact and effect on the nurses' job satisfaction as well as improving the nurses' work - life [37]. In terms of the perception on commitment, the research done by Upadhyay, validated that the involvement of employees in the QCC has strengthen their organizational commitment as well as the organizational effectiveness [38]

3. The ratings of the QCC members on the contribution of various people in the organization

Contribution in descending order of importance indicates that the circle leader as well as the other QCC members and the management have tremendous contribution, to be $4.63,4.62$ and 4.61 respectively. On the other hand, the unit supervisor, steering committee and person involved have considerable contribution to be $4.42,4.40$ and 4.45 respectively while the circle facilitator has 4.38 . For the respondents, the union is the least that has contribution (1.25) For the Hypothesis: There is no significant relationship between QCC effectiveness and Leadership in QCC. The test of relationship between the QCC effectiveness and the leadership of Quality Control Circle of Nestle Waters showed that there is no significant relationship established between the effectiveness and the leadership of Quality Control Circle of Nestle Waters: rvalue of -0.020 and p-value of 0.877 , at 0.05 level of significance. Hence, the null hypothesis, which states that there is no significant relationship between the effectiveness and the leadership of Quality Control Circle of Nestle Waters, is hereby accepted.

Findings of the research are as follows:

1. On the relationship of training adequacy to QCC effectiveness and the leadership of the Quality Control Circle (QCC), as per results, there is no relationship between adequacy of training and QCC effectiveness. It means that although trainings were given which are all related to making the QCC effective, the people who have attended the seminars and training did not consider these seminars and trainings to be helpful for them to become effective. . However, when it comes to correlation between training adequacy and the leadership of QCC, a very high correlation resulted. This simply means that the trainings that were given to were very helpful to the leaders of the QCC. The leaders were able to benefit from the seminars and training and make use of the things they have learned while carrying out their duties as leaders in the QCC.

2. On the general feeling of members towards the Quality Control Circle and the organization, the employees have a positive feelings and /or perceptions about the Quality
Control Circle. They look at the implementation of the QCC as a positive thing that is helpful for the company. On the other hand they have a strong commitment for the company.

3. About the perception of the QCC members on Job satisfaction and commitment to organizational goals and values, respondents find it important that there the employees are happy and satisfied about their job. It is also important to be able to identify themselves with the goal and values which the company believes.

4. On rating the contribution of various people in the organization, the respondents, everyone within the organization is very important as each one has his own contribution. However, based on the responses, employees do not believe that the presence of a labor union is of importance to the organization

\section{IV.CONCLUSION}

The findings resulted to the following conclusions:

1. Trainings are helpful for each and everyone in the company, to understand the importance and significance of Quality Control Circle. People who are part of the QCC but not leaders did not benefit much from the various seminars and trainings. This is evident as the result of the relationship between training adequacy and effectiveness showed negative results. It can be that the focus of the seminars given by the company was not at all applicable to members of the QCC. However, it can be concluded that the seminars and trainings worked positively for the leaders as respondents perceived that the QCC leadership became effective.

2. About the QCC and the Organization, the respondents gave positive responses that proved how happy they are with the organization and their commitment to put extra effort for the QCC.

3. About the perception of the QCC members on Job satisfaction and commitment to organizational goals and values, it is the conclusion of the researcher that respondents can see the importance that the employees are happy and satisfied about their job. Based from the responses, it also showed that respondents valued that they are able to identify themselves with the goal and values which the company believes.

4. As per result, it can be concluded that based from the responses of the employees, they believe that within the organization, everybody is important. Each one has his own contribution for the achievement of the organizational goal in general. It is also concluded that Nestle Waters employees do not see the presence of a labor union is of importance to the organization.

\section{ACKNOWLEDGMENT}

My deepest gratitude to the Nestle Waters personnel, especially to Ms. Yanna, the coordinator, Mr Thair Hamad, Factory Manager, Mr Fayez, Head of Quality, Mr Shahid, HR, who made the possibility to conduct this research. My sincere thanks also to Mr Romiro Bautista for doing the data analysis and to Dr Fely Dy Kam for introducing me to the International Advanced Research Journal in Science, Engineering and Technology. 


\section{REFERENCES}

[1] Jay Heizer and Barry Render, (2010) Operations Management, $10^{\text {th }}$ Edition, Published by Prentice Hall, ISBN 13-978-0132163927

[2] Michael Hitt, R. Duanne Ireland, et, al (2014) Strategic Management Concepts: Competiveness and Globalization, $11^{\text {th }}$ Edition, Published by Cengage Learning.

[3] Kevin Hasset (2012), Rethinking Competitiveness, Published by AEI Press, ISBN 978 - 0844772509.

[4] Edwin Leonard, (2013) Supervision: Concepts and Practices of Management, Published by Cengage Learning. ISBN-13 978-1111969790

[5] Max H Bazermann and Don A Moore (2012), Judgement in Managerial Decision Making, $8^{\text {th }}$ Edition, Published by Wiley Publishing House, ISBN-13-0978 1118065709

[6] Richard J Schonberger (1983) , Work Improvement Programme: Quality Control Circle Compared with Traditional Western Approaches, Published in International Journal of Operations and Production Management, Vol 3 Issue No 2. MCB UP Ltd. ISSN - 0144-3577

[7] Mark Davis and Janelle Heineke, (2004), Operations Management: Integrating Manufacturing and Services, $5^{\text {th }}$ Edition, Published by McGraw Hill, ISBN 987-0072948240

[8] Jay Heizer and Barry Render, (2010) Operations Management, $10^{\text {th }}$ Edition, Published by Prentice Hall, ISBN 13-978-0132163927

[9] William Stevenson, (2011) Operations Management, $11^{\text {th }}$ Edition, Published by Mc Graw Hill, ISBN-13-978-0073525259

[10] Center for Chemical Process Safety, (2012) , Guidelines for Engineering Design for Process Safety, Kindle Edition , $2^{\text {nd }}$ Edition, Published by Wiley - AIChe, ASIN: B00A4ZK4NE

[11] International Journal of Occupational and Environmental Health, Volume 20, issue 2 April 2014, ISSN: 10773525

[12] William Stevenson, (2011) Operations Management, $11^{\text {th }}$ Edition, Published by Mc Graw Hill, ISBN-13-978-0073525259

[13] Eric Smith, ( 2014 ) Workplace Security Essentials : A Guide for Helping Organizing, Creating Safe Work Environment, Published by Elsevier Publishing Company, ISBN-13- 978-0124165571

[14] Dale H, Besterfield and Carol Besterfield Michna (2003), Published by Pearson Education, ISBN - 817758412X

[15] Rozana Huq and Wilkinson Adriane, ( 2010 ) Employee Empowerment, the Rhetoric and the Reality, $1^{\text {st }}$ edition, Published by Triarchy Press, United Kingdom, ISBN - 978-0-956537966

[16] David Fetterman and Abraham Wandersman, (2004), Empowerment Evaluation in Practice, Published by Guilford Press, New York, ISBN 1-59385-114-6

[17] Victor Sower, (2010) Essentials of Quality with Cases and Experiential Exercises, Published by Technomic Publishing Company, ISBN 0470509597

[18] Joseph Defeo, (2014), Juran's Quality Essentials For Leaders, Published by Mc- Graw Hills Education, ISBN 9780071825979

[19] Shyam Bhatawdekar and Kalpana Bhatawdekar, (2012) Essentials of Quality Control Circle, Volume 4, Published by Create Space Publishing Platform, ISBN 13-978-1481095631

[20] Kaoru Ishikawa, (2014), Introduction to Quality Control, Published by Springer, ISBN-13: 0978-9401176903

[21] Christina Baldwin, (1988), Calling the Circle: the First and Future Culture, Published by Bantam: Rep Sub Ed, ISBN - 13: 978-0553379006

[22] Total Quality Management by the Ministry of Industry and Commerce, Kingdom of Bahrain, http://www.moic.gov.bh/En/ Commerce/StandardizationConsumerProtection/StandardsMetrolog yDirectorate/ISO \%20Standards\%20For\%20Management $\% 20$ Syste ms/Pages/TQM\%20Activities.aspx

[23] GARMCO Plans Investment of $\$ 50 \mathrm{M}$ to bolster Capacity, Gulf Daily News, December 2014 Edition, http://www.gulf-dailynews.com/NewsDetails.aspx?storyid $=381000$

[24] Implementing an Integrated Approach to Total Quality Management, http://www.emirates.com/english/ about/news/news__ detail.aspx? Article $=211339$

[25] How Quality Control Circles Enhance Work Safety, A Case Study, Salaheldin I. Salaheldin (Department of Management and Marketing, College of Business and Economics, University of Qatar, Doha, Qatar) and Mohamed Zain (Department of Management and Marketing, College of Business and Economics, University of Qatar, Doha, Qatar, http://www.emeraldinsigh t.com/doi/abs/10.1108/09544780710745658? journalCode=tqm

[26] The role of quality control circles in sustained improvement of medical quality, by Lin-run Wang, Yang Wang*, Yan Lou, Ying Li and Xingguo Zhang, http://www.springerplus.com/content/ pdf/2193-1801-2141.pdf
[27] Quality Circles, http://www.inc.com/encyclopedia/quality-circles.html

[28] Richard J Schonberger (1983) , Work Improvement Programme: Quality Control Circle Compared with Traditional Western Approaches, Published in International Journal of Operations and Production Management, Vol 3 Issue No 2. MCB UP Ltd. ISSN - 0144-3577

[29] Quality Circle as an Effective Management Tool: A Case Study of Indira College of Engineeringand Management Library, ( 2009 ) by Vishal V. Gaikwad and Anita V. Gaikwad, ICAL.

[30] Quality Control Circles,- the implementation of QCC in Malaysia, it's Advent and Success, by Suhaiza Hanim Mohamad Zailani, http://www.palgravejournals.com/ori/journal/v11/n2/abs/ori199811a.html.

[31] Research Methodology: A Step by Step Guide for Beginners by Ranjit Lumar, (2014), SAGE Publication Limited, ISBN 978144629978.

[32] Effects of Quality Circle Participation on Employees Perception and Attitude in 5 Malaysian Company by $\mathrm{T}$ R Abo-Alhol, M Y Ismail, et al , 2006 , Department of Mechanical and Manufacturing Engineering, Universiti Putra Malaysia.

[33] Scales and Measures by David Garson, ( 2013), Kindle Edition, ASIN B00A2ZTHX4

[34] Designing and Conducting Mixed Research by John Creswell and Vicki Clark, (2010), SAGE Publication Limited, ISBN 9781412975179.

[35] Impact of Quality Circle Towards Employees and Organization by Rajesh Chaudhary, IOSR Journal of Engineering, Volume 2, Issue No 10, October 2012, 3-ISSN - 2250-3021.

[36] The Impact of Quality Circle on Employees Work behavior : A Cross Organizational Study by Kimberly Buch, Iowa State University, Iowa

[37] The Effecr of Quality Circle on Job Satisfaction and Quality of Work Life of the Staff in Emergency Medical Service by Rezza Hosseinabadi, International Emergency Nursing, Volume 21, Issue 4, October 2013.

[38] The Role of Quality Circle in Enhancing Organizational Commitment and Organizational Effectiveness by Bal Khrisna Upadhyay, International Journal of Management Prudence, Volume 3, Issue NO 1.

[39] Effects of Trainings on Employee Performance by Jerry Shaw.

[40] Boosting Employee Engagement by Gregory Smith.

[41] Measuring Organizational Impact of Quality Circles, 1981, by Tortorich, Thompson, et al. Quality Circle Journal.

[42] Japanese Quality Circle and Productivity, 1982 by Ross and Ross, Reston Publishing.

[43] An Evaluation Study of the Quality Circle Program, 1982, by Novelli, Mohrman, et.al, A Paper Presented in the Academy of Management Annual Meeting, New York.

[44] Effects of Quality Circle on Employee Attitude in a Department of Defense Organization, 1988 by Lee L. Shaw, Air Force Institute of Technology, Air Force Base, Ohio

\section{BIOGRAPHY}

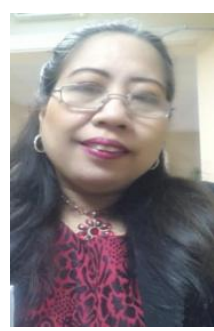

Dr Marluna Lim Urubio completed her Bachelor of Science in Management and Industrial Engineering from Mapua Insttitute of Technology while she took her Master in Engineering Management with specialization in Manufacturing Management from Pamantasan ng Lungsod ng Maynila. She earned her $\mathrm{Ph} . \mathrm{D}$ in Technology Management from the Technological University of the Philippines. Her dissertation is about the solar technology implementation in the Philippines. She has taught in Mapua Institute of Technology as well as De La Salle University Dasmarinas where she was Dean of Engineering, Architecture and Technology. She presented lectures in Widja Mandala Catholic University in Surabaya Indonesia and has a wide industry exposure in semiconductor industry. Currently, she is an Assistant Professor in the College of Administrative and Financial Sciences and concurrently the Head of Planning and Development Office at AMA International University Bahrain 
International Advanced Research Journal in Science, Engineering and Technology

Vol. 3, Issue 1, January 2016

Table 1 Interpretation for the General Perceptions about Quality Control Circle and the Organization

$\begin{array}{lll}\text { Mean } & \text { Mean range } & \text { Interpretation } \\ 5 & 4.51-5.00 & \text { Strongly Agree } \\ 4 & 3.51-4.50 & \text { Somewhat Agree } \\ 3 & 2.51-3.50 & \text { Have no opinion } \\ 2 & 1.51-2.50 & \text { Somewhat Disagree } \\ 1 & 1.00-1.50 & \text { Strongly Disagree }\end{array}$

Table 2 Interpretation of the QCC importance to Job Satisfaction and Commitment to Organizational Goal

$\begin{array}{lll}\text { Mean } & \text { Mean range } & \text { Interpretation } \\ 5 & 4.51-5.00 & \text { Extremely Important } \\ 4 & 3.51-4.50 & \text { Somewhat Important } \\ 3 & 2.51-3.50 & \text { Neither Important or Unimportant } \\ 2 & 1.51-2.50 & \text { Somewhat Unimportant } \\ 1 & 1.00-1.50 & \text { Extremely Unimportant }\end{array}$

Table 3 Interpretation on the Contribution Of various People in the Organization

$\begin{array}{lll}\text { Mean } & \text { Mean range } & \text { Interpretation } \\ 5 & 4.51-5.00 & \text { Tremendous Contribution } \\ 4 & 3.51-4.50 & \text { Considerable Contribution } \\ 3 & 2.51-3.50 & \text { Moderate Contribution } \\ 2 & 1.51-2.50 & \text { Very Little Contribution } \\ 1 & 1.00-1.50 & \text { No Contribution }\end{array}$

Table 4 Relationship of Training Adequacy to Effectiveness and Leadership of the QCC

$\begin{array}{llcc} & & \text { Adequacy of training } & \begin{array}{c}\text { Importance of training in } \\ \text { solving problems } \\ \text { Adequacy of training }\end{array} \\ & \text { Pearson Correlation } & 0.694 * * * & 0.062 \\ & \text { Sig. (2-tailed) } & 0.000 & 0.639 \\ & \mathrm{~N} & 60 & 60\end{array}$

**. Correlation is significant at the 0.01 level (2-tailed).

Table 5 General Feeling about the QCC and The Organization

\begin{tabular}{|c|c|c|}
\hline & Mean & Interpretation \\
\hline $\begin{array}{l}\text { I am happy to put extra effort for this company } \\
\text { And be a part of the company's QCC }\end{array}$ & 4.60 & Strongly Agree \\
\hline $\begin{array}{l}\text { I tell my neighbors and friends that this company is an excellent } \\
\text { company }\end{array}$ & 4.50 & Strongly Agree \\
\hline $\begin{array}{l}\text { This company is important to me that is why I give extra effort to make } \\
\text { improvements through the QCC }\end{array}$ & 4.57 & Strongly Agree \\
\hline I would quit my job tomorrow If I could get an equal or better job & 1.25 & Strongly Disagree \\
\hline I do my best everyday for the company & 4.57 & Strongly Agree \\
\hline $\begin{array}{l}\text { The goals and values that I have are similar to those of the } \\
\text { company/management }\end{array}$ & 4.50 & Strongly Agree \\
\hline Composite Mean & 3.99 & Somewhat Agree \\
\hline
\end{tabular}


Table 6 Perception of QCC members on Job Satisfaction and Commitment to Organizational Goals and Values

Co Commitment and participation in the QCC

A Aggressiveness of members

Ability of members

Ability and commitment of leader

A Ability and commitment of facilitator

Co Cooperation among Circle Members

$\mathrm{T}$ Training received by Members

Management recognition of the circles

Q QCC ave
Mean Int Interpretation

$\begin{array}{rlr}4.47 & \text { S } & \text { Somewhat } \\ 4.70 & \begin{array}{l}\text { Important } \\ \text { So }\end{array} & \text { Somewhat } \\ 4.51 & \text { Important } & \\ 4.54 & \text { So Extremely Important } \\ 4.45 & \text { Ex Extremely Important } \\ 4.48 & \text { So } & \text { Somewhat } \\ 4.47 & \text { So } & \text { Somportant } \\ 4.49 & \text { So Somewhat } & \text { So Somewhat Important } \\ 4.51 & \text { So Extremely Important }\end{array}$

Table 7 Contribution of Various People In the Organization

$\begin{array}{llll} & & \text { M } & \text { Int Interpretation } \\ \text { Ci } & \text { Circle Leader } & 4.63 & \text { Tr Tremendous Contribution } \\ \text { O Other QCC members } & 4.62 & \text { Tr Tremendous Contribution } \\ \text { M Management } & 4.61 & \text { Tr Tremendous Contribution } \\ \text { Yo Yourself } & 4.45 & \text { Co Considerable Contribution } \\ \text { U Unit Supervisor } & 4.42 & \text { Co Considerable Contribution } \\ \text { St Steering Committee } & 4.40 & \text { Co Considerable Contribution } \\ \text { Cir Circle facilitator } & 4 & \text { Co Considerable Contribution } \\ & 4.38 & \\ \text { U Union } & 1.25 & \text { N Considerable Contribution } \\ \text { Co Composite Mean } & 3 . & \text { Co Considerable Contribution } \\ & & 4.09 & \end{array}$

Table 8 Relationship Between Effectiveness and Leadership in QCC

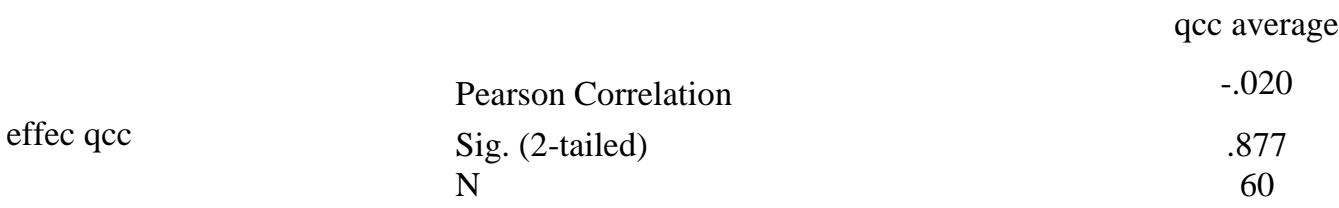

